\title{
Synthesis of new series of 4, 5-dihydroisoxazole-5-carboxylate derivatives for the study of their liquid crystalline properties
}

\author{
SUMANA Y KOTIAN ${ }^{\mathrm{a}, *}$, NARAYANA U KUDVA ${ }^{\mathrm{a}}$, K M LOKANATHA RAI ${ }^{\mathrm{a}, *}$ \\ and K BYRAPPA ${ }^{\mathrm{b}}$ \\ ${ }^{a}$ Department of Chemistry, University of Mysore, Manasagangotri, Mysuru, Karnataka, India \\ ${ }^{\mathrm{b}}$ Center for Materials Science and Technology, Vijnana Bhavan, University of Mysore, Manasagangotri, \\ Mysuru, Karnataka, India \\ e-mail: sumanakotian@gmail.com; kmlrai@yahoo.com
}

MS received 21 March 2015; revised 4 May 2016; accepted 16 May 2016

\begin{abstract}
A new series of 4,5-dihydroisoxazole-5-carboxylate derivatives were synthesized via [3+2] cycloaddition reaction between ethyl acrylate and nitrile oxide generated in situ in presence of Chloramine-T. The synthesized derivatives were characterized by Mass, IR and NMR Spectroscopy and their mesomorphic behavior were studied using DSC and Polarising Optical Microscopy.
\end{abstract}

Keywords. Dihydroisoxazole; Liquid crystals; Heterocycles.

\section{Introduction}

Since the discovery of liquid crystalline phase, by Friedrich Reinitzer, many liquid crystals have been synthesized and they have made their way to technological applications, especially as LCD's whose commercialization started way back in 1960s. ${ }^{1}$ The driving force for the formation of mesophases is intermolecular interactions such as hydrogen bonding, dipoledipole interactions and $\pi-\pi$ interaction between the molecules. ${ }^{2}$ Molecular geometry and anisotropy are important aspects for the formation of mesophases, and many such materials are known involving small molecules, ${ }^{3-5}$ polymers, ${ }^{6-8}$ biological materials such DNA $^{9,10}$ and membranes, ${ }^{11}$ heterocyclic compounds like oxadiazole, ${ }^{12,13}$ thiadiazole,${ }^{14}$ imidazole, ${ }^{15}$ and isoxazole. ${ }^{16}$ Our interest in synthesizing isoxazoline derivatives comes from the ease of synthesis and excellent mesomorphic behavior exhibited by them. ${ }^{17-19}$ The 1,3-dipolar cycloaddition reaction of a nitrile oxide generated in situ to an alkene or alkyne has proven to be very useful in the preparation of a variety of compounds in organic chemistry. ${ }^{20}$ The construction of the isoxazoline rings by this method forms an easy way to prepare a molecular base for the synthesis of attractive, non-polymer liquid-crystalline materials.

*For correspondence

\section{Experimental}

\subsection{Materials and Methods}

The chemicals, viz., 4-hydroxy benzaldehyde, n-bromo alkyl halides (for $\mathrm{n}=5,6,7,8,10,12$ and 16) were procured from LOBA chemie, India. Hydroxylamine hydrochloride was procured from SRL, India. Sodium acetate, potassium carbonate, diethyl ether were procured from RANKEM, India. Ethanol was procured from CHANGSHU YANGYUAN CHEMICAL, China. Ethylacrylate was procured from SDFCL, India. Silica gel (60-120 mesh size) for column chromatography was procured from LOBA chemie, India. The proposed structure for the intermediate compounds and that of the final compound were confirmed by the ${ }^{1} \mathrm{H}-\mathrm{NMR}$ spectra obtained using an AGILENT (400 MHz) NMR spectrometer (Dueterated chloroform as solvent procured from SIGMA ALDRICH, USA and Tetramethyl Silane as internal standard). The following notations denoted the peak types in the spectra: singlet (s), doublet (d), doublet of doublets (dd), triplet (t), quartet (q) and multiplet $(\mathrm{m})$. Infrared spectra (IR) were obtained using a Perkin Elmer spectrophotometer. The ${ }^{1} \mathrm{H},{ }^{13} \mathrm{C}$ NMR and IR spectra were used for the confirmation of the molecular structure, hydrogen bonding and the purity of samples. Differential Scanning Calorimetry (DSC) thermograms were obtained using a Perkin-Elmer DSC 7, with a TAC 7/PC interface and a controlled cooling accessory. Heating rate was $1^{\circ} \mathrm{C} \min ^{-1}$. The LC phases were characterized by their textural studies carried out 
using an Olympus BH-2 polarizing microscope, fitted with a Mettler FP52 hot stage and a Mettler FP5 controller. Samples were prepared as thin films between a glass slide and a glass cover slip. Column chromatography was carried out using silica gel (60-120 mesh) as the stationary phase. Thin layer chromatography (TLC) was carried out on aluminum sheets coated in Merck Kieselgel silica gel 60, eluting with petroleum ether and ethyl acetate $(20 \%)$.

\subsection{General procedure for synthesis of alkylated benzaldehyde ${ }^{21}$ (2a-g)}

Mixture of p-hydroxy benzaldehyde $(\mathbf{1}, 1 \mathrm{mmol})$ and n-alkyl bromide $(1 \mathrm{mmol})$ and $\mathrm{K}_{2} \mathrm{CO}_{3}(3 \mathrm{mmol})$ in dimethyl formamide $(20 \mathrm{~mL})$ were stirred for $8 \mathrm{~h}$ at room temperature $25^{\circ} \mathrm{C}$. The solid product was extracted into ether layer and it was dried over anhydrous $\mathrm{Na}_{2} \mathrm{SO}_{4}$.

\subsection{General procedure for synthesis of aromatic aldoximes $^{22}$ (3a-g)}

n-alkylated benzaldehyde $(1.0 \mathrm{mmol})$ in $15 \mathrm{~mL}$ ethanol was added to a solution of hydroxylamine hydrochloride $(1.4 \mathrm{mmol})$ and sodium acetate $(1.4 \mathrm{mmol})$ in water and the mixture was heated at $80-90^{\circ} \mathrm{C}$ for $1 \mathrm{~h}$. After completion of the reaction, it was allowed to cool to room temperature, precipitated aldoxime was collected and purified by crystallization from ethanol to give compounds (3a-g).

\subsection{General procedure for synthesis of isoxazoline derivative $^{22}$ (4a-g)}

Ethyl acrylate ( $1 \mathrm{mmol})$, aldoxime (1 mmol) and chloramine-T $(1.5 \mathrm{mmol})$ in ethanol $(20 \mathrm{~mL})$ were taken in a reaction flask and it was stirred for $8 \mathrm{~h}$ at $25^{\circ} \mathrm{C}$. The completion of the reaction was monitored by TLC. After completion, sodium chloride formed was filtered off and washed with ethanol $(15 \mathrm{~mL})$. Filtrate and washing were combined and the solvent was evaporated in vacuum. The residue was extracted with ether $(25 \mathrm{~mL} \times 3)$, the extract was washed successively with water $(15 \mathrm{~mL} \times 2), 10 \% \mathrm{NaOH}(15 \mathrm{~mL} \times 2)$, and saturated brine solution $(10 \mathrm{~mL})$. The organic layer was dried over anhydrous $\mathrm{Na}_{2} \mathrm{SO}_{4}$. The crude product was filtered and purified by column chromatography on silica gel using a mixture of petroleum ether: ethyl acetate to give the corresponding pure product (scheme 1).

2.4a Ethyl 3-[4-(pentyloxy)phenyl]-4,5-dihydroisoxazole-5-carboxylate (4a): FT-IR $\left(\mathrm{cm}^{-1}\right)$ : 2935, 1732, 1421, 1346, 1299. ${ }^{1} \mathrm{H}$ NMR $\left(\mathrm{CDCl}_{3}, 400 \mathrm{MHz}\right) \delta: 7.58$ $(\mathrm{d}, \mathrm{J}=8.8 \mathrm{~Hz}, \operatorname{ArH}, 2 \mathrm{H}), 6.88(\mathrm{~d}, \mathrm{~J}=8.8 \mathrm{~Hz}, \operatorname{ArH}$, 2H) $5.10(\mathrm{dd}, \mathrm{J}=10.4,8 \mathrm{~Hz}, \mathrm{OCH}, 1 \mathrm{H}), 4.25(\mathrm{q}$, $\left.\mathrm{OCH}_{2}, 2 \mathrm{H}\right) 3.95$ (t, $\left.\mathrm{OCH}_{2}, 2 \mathrm{H}\right) 3.57-3.54\left(\mathrm{~m}, \mathrm{CH}_{2}, 2 \mathrm{H}\right)$ 1.79-1.28 (m, $\left.\mathrm{CH}_{2}, \mathrm{CH}_{3}, 9 \mathrm{H}\right), 0.915\left(\mathrm{t}, \mathrm{CH}_{3}, 3 \mathrm{H}\right) .{ }^{13} \mathrm{C}$ NMR $\left(\mathrm{CDCl}_{3}, 100 \mathrm{MHz}\right) \delta: 13.95,14.07,22.39,28.11$, 28.90, 39.10, 61.91, 68.12, 76.69, 77.79, 77.83, 114.67, 120.44, 120.81, 155.56, 160.95, 170.38 LCMS: 306.25 $[\mathrm{M}+\mathrm{H}]+$. Elemental Analysis: C-66.78; H-7.29; N4.44\%. Yield: $83 \%$.

2.4b Ethyl 3-[4-(hexyloxy)phenyl]-4,5-dihydroisoxazole5-carboxylate (4b): FT-IR $\left(\mathrm{cm}^{-1}\right)$ : 2931, 1738, 1421, 1350, 1303. ${ }^{1} \mathrm{H}$ NMR $\left(\mathrm{CDCl}_{3}, 400 \mathrm{MHz}\right) \delta: 7.60(\mathrm{~d}$, $\mathrm{J}=8.8 \mathrm{~Hz}, \operatorname{ArH}, 2 \mathrm{H}) 6.90(\mathrm{~d}, \mathrm{~J}=8.8 \mathrm{~Hz}, \operatorname{ArH}, 2 \mathrm{H})$, $5.13(\mathrm{dd}, \mathrm{J}=10.4,8 \mathrm{~Hz}, \mathrm{OCH}, 1 \mathrm{H}) 4.27\left(\mathrm{q}, \mathrm{OCH}_{2}\right.$, $2 \mathrm{H}) 3.94\left(\mathrm{t}, \mathrm{OCH}_{2}, 2 \mathrm{H}\right) 3.65-3.62\left(\mathrm{~m}, \mathrm{CH}_{2}, 2 \mathrm{H}\right), 1.35-$ $1.27\left(\mathrm{~m}, \mathrm{CH}_{2}, \mathrm{CH}_{3}, 11 \mathrm{H}\right), 0.9$ (t, $\left.\mathrm{CH}_{3}, 3 \mathrm{H}\right) .{ }^{13} \mathrm{C} \mathrm{NMR}$ $\left(\mathrm{CDCl}_{3}, 100 \mathrm{MHz}\right) \delta: 14.01,14.10,22.57,25.65,29.68$, $31.53,39.12,61.95,68.13,77.01,77.32,77.83,114.66$, 120.78, 128.46, 155.57, 160.94, 170.42. LCMS: 319.97 $[\mathrm{M}+\mathrm{H}]+$. Elemental Analysis: C-67.65; H-7.80; N- 4.22. Yield: $78 \%$.

2.4c Ethyl 3-[4-(heptyloxy)phenyl]-4,5-dihydroisoxazole5-carboxylate (4c): FT-IR $\left(\mathrm{cm}^{-1}\right)$ : 2925, 1735, 1414, 1352, 1304. ${ }^{1} \mathrm{H}$ NMR $\left(\mathrm{CDCl}_{3}, 400 \mathrm{MHz}\right) \delta: 7.58$ (d, $\mathrm{J}=8.8 \mathrm{~Hz}, \operatorname{ArH}, 2 \mathrm{H}), 6.87(\mathrm{~d}, \mathrm{~J}=8.8 \mathrm{~Hz}, \operatorname{ArH}, 2 \mathrm{H})$,

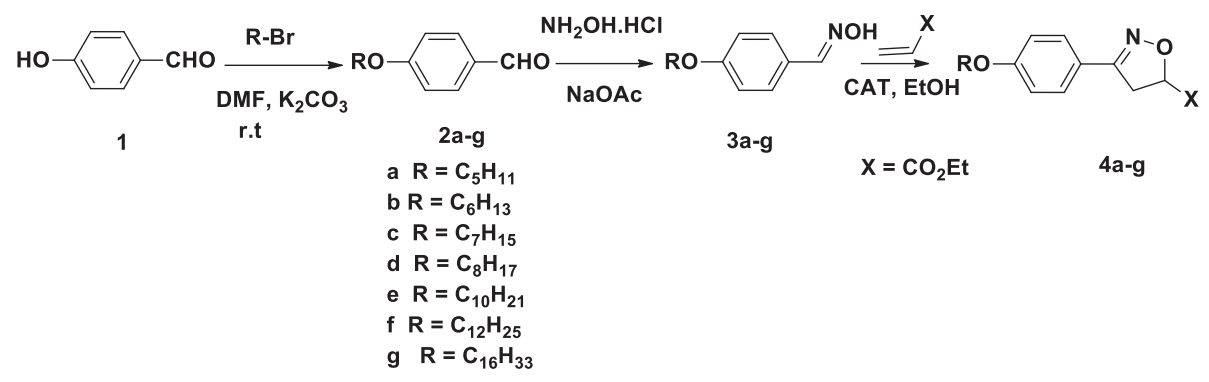

Scheme 1. General reaction schemes for products 2a-g, 3a-g and 4a-g. 
$5.08(\mathrm{dd}, \mathrm{J}=10.4,8 \mathrm{~Hz}, \mathrm{OCH}, 1 \mathrm{H}), 4.26\left(\mathrm{q}, \mathrm{OCH}_{2}\right.$, $2 \mathrm{H}), 3.97\left(\mathrm{t}, \mathrm{OCH}_{2}, 2 \mathrm{H}\right), 3.60-3.57\left(\mathrm{~m}, \mathrm{CH}_{2}, 2 \mathrm{H}\right)$, 1.65-1.27 (m, $\left.\mathrm{CH}_{2}, \mathrm{CH}_{3}, 13 \mathrm{H}\right), 0.86\left(\mathrm{t}, \mathrm{CH}_{3}, 3 \mathrm{H}\right)$. ${ }^{13} \mathrm{C}$ NMR $\left(\mathrm{CDCl}_{3}, 100 \mathrm{MHz}\right) \delta: 14.04,14.09,22.56$, 25.92, 28.99, 31.73, 39.11, 61.93, 68.14, 76.67, 76.98, 77.30, 77.85, 114.67, 120.80, 128.45, 155.56, 160.95, 170.39. LCMS: $334.24[\mathrm{M}+\mathrm{H}]+$. Elemental Analysis (\%): C-68.39; H-8.11; N- 4.15. Yield: $81 \%$.

2.4d Ethyl 3-[4-(octyloxy)phenyl]-4,5-dihydroisoxazole5-carboxylate (4d): FT-IR $\left(\mathrm{cm}^{-1}\right): 2920,1733,1418$, 1354, 1309. ${ }^{1} \mathrm{H}$ NMR $\left(\mathrm{CDCl}_{3}, 400 \mathrm{MHz}\right) \delta: 7.58(\mathrm{~d}$, $\mathrm{J}=8.8 \mathrm{~Hz}, \mathrm{ArH}, 2 \mathrm{H}), 6.88(\mathrm{~d}, \mathrm{~J}=8.8 \mathrm{~Hz}, \operatorname{ArH}, 2 \mathrm{H})$, $5.10(\mathrm{dd}, \mathrm{J}=10.4,8 \mathrm{~Hz}, \mathrm{OCH}, 1 \mathrm{H}), 4.24\left(\mathrm{q}, \mathrm{OCH}_{2}\right.$, $2 \mathrm{H}), 3.96\left(\mathrm{t}, \mathrm{OCH}_{2}, 2 \mathrm{H}\right), 3.60-3.57\left(\mathrm{~m}, \mathrm{CH}_{2}, 2 \mathrm{H}\right)$, 1.41-1.25 (m, $\left.\mathrm{CH}_{2}, 15 \mathrm{H}\right), 0.86\left(\mathrm{t}, \mathrm{CH}_{3}, 3 \mathrm{H}\right) .{ }^{13} \mathrm{C} \mathrm{NMR}$ $\left(\mathrm{CDCl}_{3}, 100 \mathrm{MHz}\right) \delta: 14.04,14.08,22.61,25.96,29.18$, 29.29, 31.76, 39.11, 61.91, 68.15, 76.66, 77.30, 77.80, 77.85, 114.69, 120.82, 128.44, 155.54, 160.96, 170.38 . LCMS: $348.22[\mathrm{M}+\mathrm{H}]+$. Elemental Analysis(\%): C-69.12; H-8.37; N- 4.01. Yield: 82\%.

2.4e Ethyl 3-[4-(decyloxy)phenyl]-4,5-dihydroisoxazole-5-carboxylate (4e): FT-IR $\left(\mathrm{cm}^{-1}\right): 2917,1732$, 1401, 1353, 1264. ${ }^{1} \mathrm{H}$ NMR $\left(\mathrm{CDCl}_{3}, 400 \mathrm{MHz}\right) \delta: 7.42$ $(\mathrm{d}, \mathrm{J}=8.8 \mathrm{~Hz}, \operatorname{ArH}, 2 \mathrm{H}), 6.88(\mathrm{~d}, \mathrm{~J}=8.8 \mathrm{~Hz}, \operatorname{ArH}$, $2 \mathrm{H}), 5.11(\mathrm{dd}, \mathrm{J}=10.4,8 \mathrm{~Hz}, \mathrm{OCH}, 1 \mathrm{H}), 4.24\left(\mathrm{q}, \mathrm{OCH}_{2}\right.$, $2 \mathrm{H}), 3.96\left(\mathrm{t}, \mathrm{OCH}_{2}, 2 \mathrm{H}\right), 3.61-3.59\left(\mathrm{~m}, \mathrm{CH}_{2}, 2 \mathrm{H}\right)$, 1.71-1.26 (m, $\left.\mathrm{CH}_{2}, \mathrm{CH}_{3}, 19 \mathrm{H}\right), 0.86$ (t, $\left.\mathrm{CH}_{3}, 3 \mathrm{H}\right) .{ }^{13} \mathrm{C}$ NMR $\left(\mathrm{CDCl}_{3}, 100 \mathrm{MHz}\right) \delta: 14.03,14.14,22.64,25.96$, 29.27, 29.52, 31.85, 39.10, 61.91, 68.14, 68.30, 76.67, 77.31, 77.71 77.94, 114.66, 120.81, 128.35, 128.53, 155.54, 160.95, 170.39. LCMS: $376.24 \mathrm{M}+$. Elemental Analysis(\%): C-70.33; H-8.90; N- 3.71. Yield: 84\%.

2.4f Ethyl 3-[4-(dodecyloxy)phenyl]-4,5-dihydroisoxazole5-carboxylate (4f): FT-IR $\left(\mathrm{cm}^{-1}\right): 2917,1740,1419$, 1357, 1307. ${ }^{1} \mathrm{H}$ NMR $\left(\mathrm{CDCl}_{3}, 400 \mathrm{MHz}\right) \delta: 7.58(\mathrm{~d}$, $\mathrm{J}=8.8 \mathrm{~Hz}, \mathrm{ArH}, 2 \mathrm{H}), 6.89(\mathrm{~d}, \mathrm{~J}=8.8 \mathrm{~Hz}, \mathrm{ArH}, 2 \mathrm{H})$, $5.11(\mathrm{dd}, \mathrm{J}=10.8,8 \mathrm{~Hz}, \mathrm{OCH}, 1 \mathrm{H}), 4.25\left(\mathrm{q}, \mathrm{OCH}_{2}\right.$,
$2 \mathrm{H}), 3.96\left(\mathrm{t}, \mathrm{OCH}_{2}, 2 \mathrm{H}\right), 3.60-3.57\left(\mathrm{~m}, \mathrm{CH}_{2}, 2 \mathrm{H}\right)$, 1.45-1.25 (m, 23H, $\left.\mathrm{CH}_{2}, \mathrm{CH}_{3}\right), 0.86\left(\mathrm{t}, \mathrm{CH}_{3}, 3 \mathrm{H}\right) .{ }^{13} \mathrm{C}$ NMR $\left(\mathrm{CDCl}_{3}, 100 \mathrm{MHz}\right) \delta: 14.07,14.11,22.61,25.97$, $29.12,29.34,29.35,29.54,29.57,29.62,29.64,39.12$, $61.97,68.13,76.67,77.31,77.80,114.66,120.76$, 128.46, 128.57, 155.71, 161.88, 170.44. LCMS: 404.05 $[\mathrm{M}+\mathrm{H}]+$. Elemental Analysis(\%): C-71.38; H-9.20; N-3.42. Yield: $82 \%$.

2.4g Ethyl 3-[4-(hexadecyloxy)phenyl]-4,5-dihydroisoxazole-5-carboxylate (4g): FT-IR $\left(\mathrm{cm}^{-1}\right)$ : 2931, $1738,1421,1350,1303 .{ }^{1} \mathrm{H} \mathrm{NMR}\left(\mathrm{CDCl}_{3}, 400 \mathrm{MHz}\right)$ $\delta: 7.74(\mathrm{~d}, \mathrm{~J}=8.8 \mathrm{~Hz}, \operatorname{ArH}, 2 \mathrm{H}), 6.96(\mathrm{~d}, \mathrm{~J}=8.8 \mathrm{~Hz}$, $\mathrm{ArH}, 2 \mathrm{H}), 5.14(\mathrm{dd}, \mathrm{J}=10.4,8 \mathrm{~Hz}, \mathrm{OCH}, 1 \mathrm{H}), 4.30$ $\left(\mathrm{q}, \mathrm{OCH}_{2}, 2 \mathrm{H}\right), 4.00\left(\mathrm{t}, \mathrm{OCH}_{2}, 2 \mathrm{H}\right), 3.61-3.57(\mathrm{~m}$, $\left.\mathrm{CH}_{2}, 2 \mathrm{H}\right), 1.53-1.20\left(\mathrm{~m}, \mathrm{CH}_{2}, \mathrm{CH}_{3}, 31 \mathrm{H}\right), 0.87$ (t, $\left.\mathrm{CH}_{3}, 3 \mathrm{H}\right) .{ }^{13} \mathrm{C} \mathrm{NMR}\left(\mathrm{CDCl}_{3}, 100 \mathrm{MHz}\right) \delta: 14.06,14.07$, $22.65,25.70,29.32,29.40,29.56,29.62,29.64,29.69$, $29.72,29.76,29.80,31.39,32.79,61.45,76.65,77.17$, $77.29,80.01,114.50,114.39,122.01,128.29,128.45$, 156.48, 161.99, 170.76. LCMS: 459.15 M+. Elemental Analysis(\%): C-73.14; H-9.83; N- 3.02. Yield: $80 \%$.

\section{Results and Discussion}

\subsection{Mesomorphic Properties}

The changes in phases were identified by Polarizing Optical microscope (figure 1) and they were found to be in agreement with DSC transition temperatures. All the synthesized derivatives were found to exhibit Nematic and Smectic phases. Smectic phase was typical in the intermediate compounds 3a-g and Nematic phase was found to be the typical phase in all the synthesized Isoxazolines 4a-g. Smectic phase was found in compounds with long chain homologues and Nematic phase was exhibited by compounds with short alkyl chain. The change in the mesomorphic phases is due to changes in the orientations and free rotation of the rings, and various orientations are stabilized at different temperatures
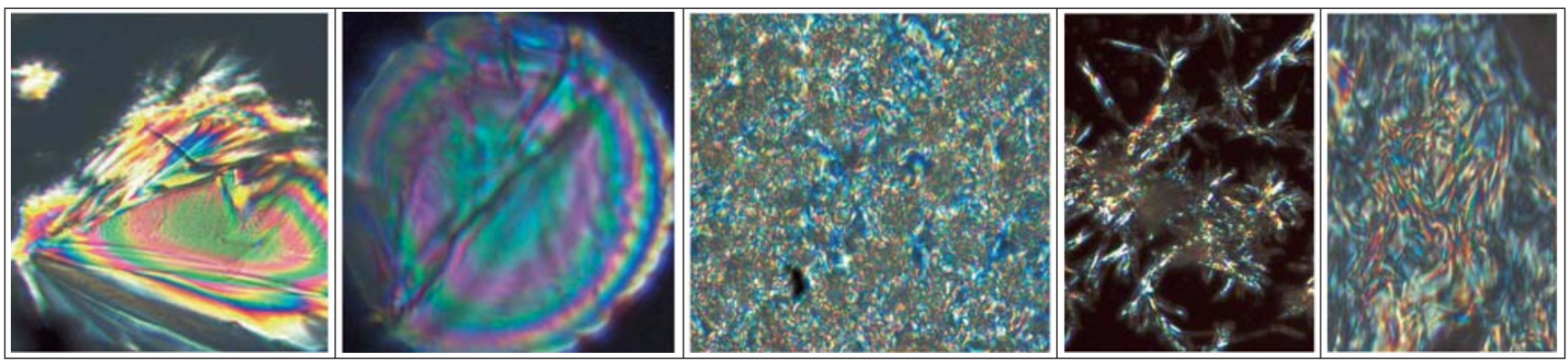

Figure 1. $\mathrm{POM}$ images of $\mathbf{3 a}$ at $22^{\circ} \mathrm{C}, \mathbf{3 b}$ at $24^{\circ} \mathrm{C}, \mathbf{5 b}$ at $9.8^{\circ} \mathrm{C}, \mathbf{5 d}$ at $24^{\circ} \mathrm{C}$ and $\mathbf{5 e}$ at $25^{\circ} \mathrm{C}$. 
leading to the changes in the phases and probably due to the non planarity. The formation of mesophase is purely a geometrical aspect. The Isotropic temperatures of the compounds 3a-g were high compared to the Isotropic temperature of the final cyclised product which proves the lowering of melting point in the presence of heterocycles. Compounds $\mathbf{4 a}$ and $\mathbf{4 b}$ were liquid in nature and they exhibited Nematic phase and the other members exhibited Smectic phases. It shows that as the alkyl chain length increases better mesophases are exhibited.

\section{Conclusions}

We found that the incorporation of the alkyl group in a new series of 4,5-dihydroisoxazole-5-carboxylate derivatives increased the liquid crystalline nature of the molecule caused by the presence of the heterocycle, and it dramatically decreased the melting point of the compounds. The design of novel thermotropic liquid crystals as advanced functional materials involves selection of suitable core fragment, linking group, and terminal functionality. Heterocycles are of great of importance as core units in thermotropic liquid crystals owing to their ability to impart lateral and/or longitudinal dipoles combined with changes in the molecular shape. The incorporation of heteroatoms can result in considerable changes in the corresponding liquid crystalline phases and/or in the physical properties of the observed phases, because most of the common heteroatoms ( $\mathrm{S}, \mathrm{O}$ and $\mathrm{N}$ ) are more polarizable than carbon.

\section{Supporting Information (SI)}

${ }^{1} \mathrm{H}$ and ${ }^{13} \mathrm{C}$ NMR, Mass, XRD and POM images are available in Supplementary Information at www.ias.ac. in/chemsci.

\section{Acknowledgements}

The authors would like to acknowledge University with Potential for Excellence (UPE), UGC for the financial support and University of Mysore for the laboratory facilities. Authors would also like to acknowledge Institute of Excellence, University of Mysore for the instrumentation facilities.

\section{References}

1. Gray G W, Harrison K J and Nash J A 1973 Electron Lett. 9130

2. Kato T, Mizoshita N and Kishimoto K 2006 Angew. Chem. Int. Ed. 4538

3. Tavares A, Ritter O M S, Vasconcelos U B, Arruda B C, Schrader A, Schneider P H and Merlo A A 2010 Liq. Cryst. 37159

4. Kauhanka U and Kauhanka M 2004 Liq. Cryst. 311547

5. Kovganko V N and Konganko N N 2006 Russ. J. Org. Chem. 42243

6. Stewart D, Mchattie G S and Imrie C T 1998 J. Mater. Chem. 847

7. Ritter O M S, da Silveira N P and Merlo A A $2006 J$. Braz. Chem. Soc. 17348

8. Rueff J M, Barbera J, Donnio B, Guillon D, Marcos M and Serrano J L 2003 Macromolecules 368368

9. Lydon J E 2003 Liq. Cryst. 121

10. Kurapati R, Reddy U V, Raichur A M and Suryaprakash N 2016 J. Chem. Sci. 128325

11. Goodby J W 2006 Liq. Cryst. 331229

12. Kandre S, Bhagat P R, Sharma R and Gupte A 2013 Tetrahedron Lett. $\mathbf{5 4} 3526$

13. Selvarasu C and Kannan P 2015 J. Chem. Sci. 127 1831

14. Gallardo H, Santos D M P de O, Caramori G F, Molin F and Bechtold I H 2013 Liq. Cryst. 40570

15. Roddecha S and Anthamatten M 2010 Liq. Cryst. 37 389

16. Haino T, Tanaka M, Ideta K, Kubo K, Morib A and Fukazawaa Y 2004 Tetrahedron Lett. 452277

17. Passo J A, Vilela G D, Schneider P H, Ritter O M S and Merlo A A 2008 Liq. Cryst. 35833

18. Aline Tavares, Paulo H Schneider and Aloir A Merlo 2009 Eur. J. Org. Chem. 889

19. Rafaela R da Rosa, Irwing S Brose, Guilherme D Vilela and Aloir A Merlo 2015 Mol. Cryst. Liq. Cryst. 612 158

20. Rai K M L and Hassner A 1997 Synth. Commun. 27 467

21. Shi Min and Shen Yu-Mei 2002 Molecules 7386

22. Raad Kasim Yhya, Lokanatha Rai K M and Ebraheem Abdu Musad 2013 J. Chem. Sci. 125799 